\title{
Serendipity in medicine and wine
}

\author{
Shaun R. McCann $\mathbb{1}^{1}$
}

Received: 10 December 2020 / Revised: 16 December 2020 / Accepted: 17 December 2020 / Published online: 8 January 2021

(c) The Author(s), under exclusive licence to Springer Nature Limited 2021

Everything you hear is an opinion, not a fact. Everything we see is a perspective not the truth.

Marcus Aurelius, Roman Emperor. (121-180 B.C.) Fig. 1

According to the Oxford English Dictionary, the term "serendipity" was coined by Horace Walpole in 1754 . He explained that he had based it on a fairy-tale, The Three Princes of Serendip, whose protagonists were always making discoveries of things for which they were not looking. Medicine is strewn with examples of serendipity, from Alexander Fleming's discovery of Penicillin, Fig. 2, to the discovery of Helicobacter Pylori as a cause of peptic ulcer disease by Barry Marshall and Robin Warren and $\mathrm{N}_{2} \mathrm{O}$ by Humphrey Davy. Dicoumarol is another example, when Karl Paul Link and Mark Arnold Stahmann noticed a Wisconsin farmer's cattle were bleeding to death. Eventually, the drug warfarin was developed and has been the mainstay of anti-coagulant therapy until relatively recently.

In terms of haematopoietic cell transplantation (HCT), probably the best example, is the serendipitous discovery of graft versus host disease (GvHD) in an animal model of HCT by Delta Uphoff [1]. Laboratory mice which had received spleen cells or bone marrow following lethal irradiation, were accidentally left is a cage for 4 weeks. Uphoff noticed that the mice had inflamed footpads and diarrhoea. Their condition was called secondary or runt disease. In 1962 Barnes and Loutit unravelled the pathobiology of the mice's condition and in 1965 Morten Simonson named the phenomenon Graft versus Host Disease (GvHD).

In 2019 the EBMT Autoimmune Diseases Working Party [2] claimed that the use of autologous HCT was clinically validated through the observation of serendipitous case reports.

Shaun R. McCann

shaunrmccann@gmail.com

1 University of Dublin Trinity College, Haematology Emeritus, Dublin, Ireland
Thalidomide, originally a drug used as a sedative during pregnancy, was withdrawn because of its teratogenic effects, notably phocomelia. Although its anti-tumour effects, have been known for over 20 years, its relatively recent use in the treatment of multiple myeloma (MM) has been widely applauded. While the drug has anti-angiogenic and immunomodulatory effects it's precise mechanism of action in MM remains unclear. Thalidomide has now largely been replaced by drugs known as IMiDs and these in combination with dexamethasone and proteasome inhibitors have significantly altered the prognosis for many patients with MM. Although the use of Thalidomide may not fit precisely within the definition of 'serendipity' its widespread use and that of its analogues, has taken the MM world by surprise. The drug has had many uses including the treatment of lapracy [3].

What is of considerable interest is that most of these serendipitous discoveries were dis-believed by the 'establishment' and took many years to be accepted. I suppose the most well-known serendipitous story about wine is the discovery of champagne by Dom Pérignon. Although widely believed, unfortunately, it is a myth [4]. Yes Champagne, with the three towns of, Reims, Épernay and Ay̆, was the first region to produce sparkling wine in quantity and, is now synonymous with celebrations, like weddings and other important events. The popularity of fine wines from Épernay and Châlons-sur-Marne was facilitated by their closeness to the Marne river which joins the Seine east of Paris. These wines were still, made from pinot noir grapes. In the 17 th century Dom Pérignon, a noted viticulturalist, transformed the Abbey of Hautvillers, above Épernay, into the region's leading viticulture centre. In the relatively cool climate of the region many grapes did not complete fermentation but underwent secondary fermentation in the bottle, often with explosive consequences. This tendency for bottles to explode was considered an irritant. These sparkling wines were considered inferior to the still wines of Champagne. It is said that London, with the encouragement of the Marquis de St -Évremond Fig. 3 who 


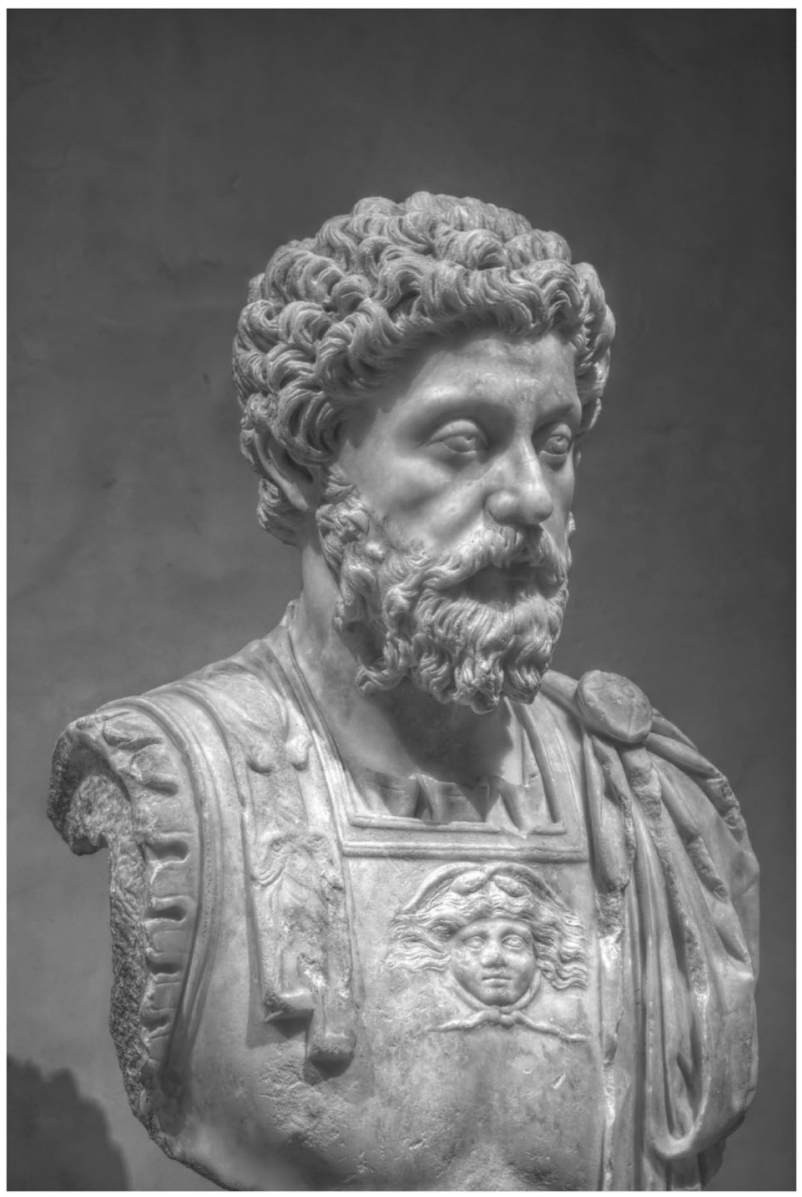

Fig. 1 Marcus Aurelius Antonius. Roman Emperor. 121-180 B.C. Creative commons attribution-share alike 3.0 Unported license. PierreSelim. L'Image et le Pouvoir: le siècle des Antonis, Musée SaintRaymond. He enjoyed a glass of wine.

had been banished in 1662 to England, was the first city to enjoy the 'bubbly' we now call champagne.

Understanding and controlling secondary fermentation took some time. Chaptal understood the phenomenon, but the credit for adding the correct amount of sugar and avoiding an explosion goes to Jean-Baptise François. Interestingly although Madame Cliquot [5] and Monsieur Moët were French, most of the champagne producers in the 19th century were from the Rhineland (Krug, Bollinger and Roederer), All was not plain sailing; phylloxera struck in 1890 and the Russian market collapsed in 1917. The final boundaries of Champagne were settled in 1927 and the grapes that are now used are pinot noir, pinot munier and chardonnay. Pinot noir accounts for just over one third of vines planted and, of course, blancs de blancs is made from chardonnay exclusively and the majority of champagnes undergo malolactic fermentation.

There are many competitors now in the USA, Germany, Spain, Australia and Italy, some of which are considerably less expensive than champagne. My preference is for

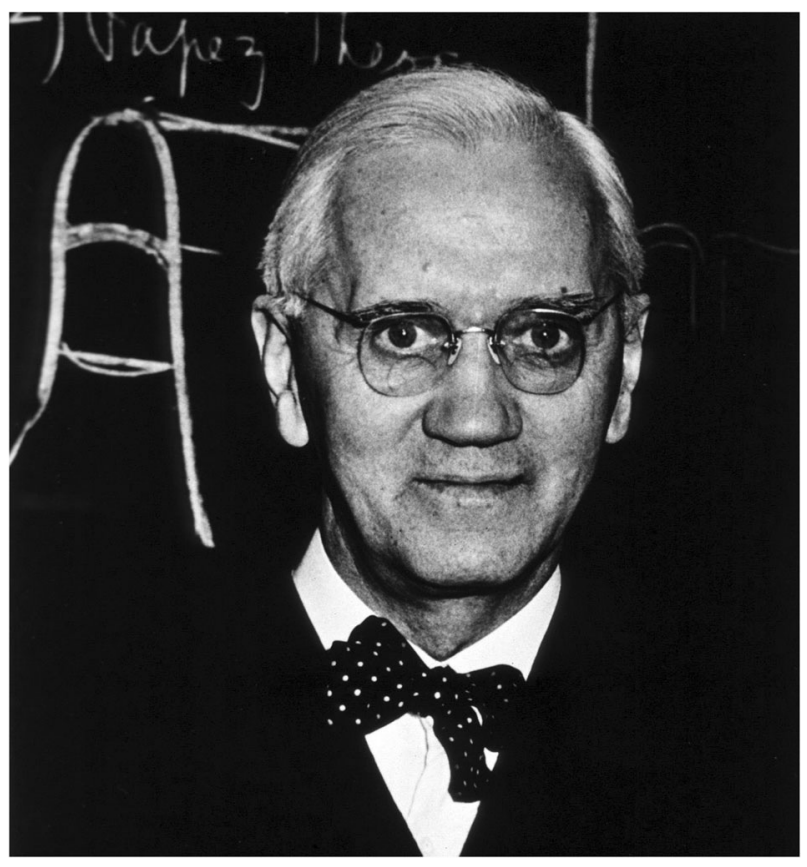

Fig. 2 Alexander Fleming. Fleming discovered lysozyme in 1922 and penicillin in 1929.

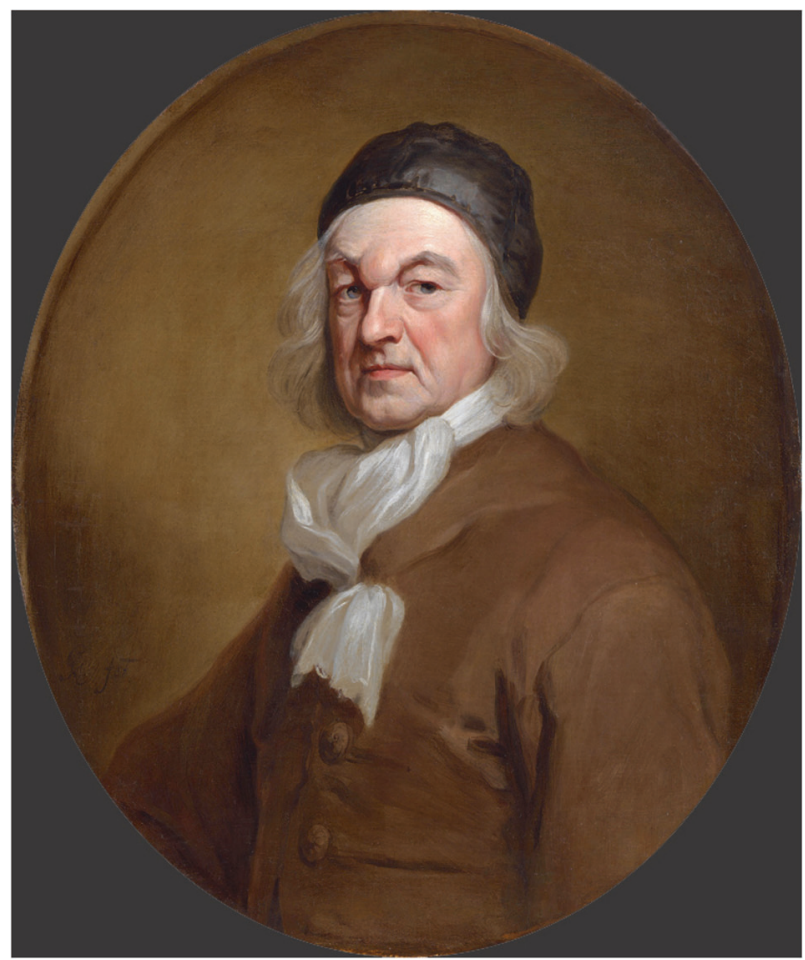

Fig. 3 The Marquis de St Évrement. He was a French man who made champagne a popular drink in London in the late 17th century. I presume the swelling on his forehead is a benign lipoma.

sparkling wines from Franciacorta in Lombardy [6] which provide a nice aperitif at a reasonable price. England has 
risen to prominence as a producer of sparkling wine and in some instances has outshone wines from Champagne. I tasted some beautiful sparkling wine from England by Steven Spurrier [7] in Castellina in Chianti recently but these wines are not inexpensive.

Covid-19 has had an effect on many aspects of life including champagne production [8]. Victor Mallet, writing in the Weekend/FT points out that although 2020 has been an excellent year for grape growing, a number of factors including a collapse of the restaurant trade and uncertainty about trade tariffs, has resulted in an expected $30 \%$ reduction in worldwide sales. This has also resulted in grapes rotting on the vines in some vineyards.

A number of vineyards have used the title serendipity in the USA, Canada, New Zealand and I'm sure there are others. Even in these dark days of Covid-19, a glass of sparkling wine might cheer you up and remember you are celebrating the serendipitous phenomenon of secondary fermentation in the bottle.

\section{Compliance with ethical standards}

Conflict of interest The author declares that he has no conflict of interest.
Publisher's note Springer Nature remains neutral with regard to jurisdictional claims in published maps and institutional affiliations.

\section{References}

1. Gale RP, McCann SR. A brief history of hematopoietic cell transplantation in Hematopoietic Cell Transplants, Concepts, Controversies and Future Directions. Lazarus HM et al, editors. UK: Cambridge University Press; 2017.

2. Snowden J, Badoglio M, Alexander T. The rise of autologous HCT for autoimmune diseases: what is behind it and what does it mean for future treatment? an update on behalf of the EBMT Autoimmune Diseases Working Party. 2019. Expert Rev Clin Immunol. https://doi.org/10.1080/1744666X.2019.1656526.

3. Rehman W, Arfons LM, Lazarus HM. The rise, fall and subsequent triumph of thalidomide: lessons learned in drug development. Ther Adv Hematol. 2011;2:291-308.

4. Robinson J, Harding J. Oxford companion to wine. $4^{\text {th }}$ ed. UK: Oxford University Press. 2015.

5. McCann SR. Sex matters in Wine and Blood: an unlikely pairing. Moldova: Elvia Press; 2020. ISBN 978-9975-3417-7-6

6. McCann SR. Patients get viral infections: so, do vines. Bone Marrow Transplant. 2019. https://doi.org/10.1038/s41409-019-0719-6

7. McCann SR. The Judgement of Paris. Bone Marrow Transplant. 2018. https://doi.org/10.1038/s41409-018-0336-9

8. Mallet V. Sour grapes. Champagne sector wrangles over price and demand falls. Weekend FT 22/23 August 2020. London, UK: Financial Times Ltd. 